\title{
Examining the Views of Students on the Orientation Program for Fresh Students in the University of Cape Coast, Ghana
}

\author{
Esther Rhoda Ababio ${ }^{1}$, Felicia Commey ${ }^{2}$ \\ ${ }^{I}$ Directorate of University Health Services, University of Cape Coast, Ghana \\ ${ }^{2}$ Department of Population and Health University of Cape Coast, Ghana
}

\begin{abstract}
The study examined the views of students on orientation programs organized for fresh students in the University of Cape Coast at the beginning of the 2019/2020 academic year. Students' involvement theory was adapted. Qualitative data was collected from purposively selected respondents and key informants in the University and analyzed using a thematic approach. The study revealed that the duration of the program was short and therefore packed which make it too stressful for the students. During the orientation exercise, some of the expectations of the students were met whilst others were not.
\end{abstract}

\section{INTRODUCTION}

$\mathrm{G}$ lobally, higher educational institutions organized an orientation for their fresh students due to the immense benefits to them. Various benefits of orientation for first-year students have been identified by scholars. Some of these benefits include easing into college life, increasing comfort with interaction among peers and faculty, raising individual retention rates, and a better understanding of one's self. According to Evensen, (2017) orientation program seeks to provide students with the opportunity to engage with the university as a whole before their academic activities commence (The relevance of fresh students' orientation is grounded in the Student involvement theory. The theory provides a platform to understand what and how environmental influences affect students' development and what kind of involvement matters to achieve a specific outcome. The theory also portrays the degree of student involvement such as quality and quantity lead to certain development aspects and how the program, curriculum, policy or practices be designed to encourage student involvement (Binti, Fadhilah \& Anuar, 2019). Student orientation takes different forms. Some take place a week before the academic semester begins, during the semester and in other cases, according to the institution's preference. Regardless of the form it takes, orientation is a university's main opportunity to introduce and integrate new students into the campus community and culture, form class and institutional identity and prepare students to begin lectures (Alnawas, 2015). According to Oladele (2000), the purpose of orientation is to help students feel emotionally secure and better adjust to a new environment, especially during a critical transition period.
Chavez (2015) defined orientation as a one-of-a-kind class designed to help incoming students make the transition from high school to a university. An institution's first-year orientation program is crucial for the development and acclimation of first-year students and a first-year student needs to experience that. A student who attends an orientation program gains many benefits (Evensen, 2017). Agi (2016) indicates that students learn the challenges, joy and expectations of academic life during orientation service. The orientation program provides the option for purposeful spaces and opportunities in which first-year students can connect and interact before their semester begins (Evensen, 2017).

The goal of an orientation program is to provide the opportunity for first-year students to engage with the university as a whole before their academic course beginning. According to Miller, Dyer, and Nadler (2002), the common overall goals for any orientation program are to build retention, foster academic skills, provide opportunities for peer interaction, encourage student maturation and development, and among other things, provide cultural awareness and broadening world view. Student orientation is designed to help students acquire much information on the school procedures and practices which they need to realign their lifestyle with the culture of the school (Owusu, Tawiah, Sena-Kpeglo \& Onyame, 2014). However, orientation programs have been organized for fresh students every year at the University of Cape Coast but the extent to which the students have been stressed up during the period is a worrying situation, which could have dire consequences on students and the quality of the orientation program in the University. Against this background, the study, guided by the Student involvement theory and examined the views of students on orientation programs organized for fresh students in the University of Cape Coast. Even though there are a few studies on orientation programs in the University the focus was not students' views on the organization of the orientation programs and their benefits to the students, the gab this paper seeks to fill.

The specific objectives are to:

1. To examine students' views on the importance of orientation programs to them. 
2. To determine the challenges students'face in adaptation to the university system.

3. To ascertain the effect of orientation on the academic and social life of the fresh students.

\section{Theoretical and conceptual discussions}

The paper is underpinned by the Student involvement theory. This theory refers to the quantity and quality of the physical and psychological energy that students invest in the university experience (Binti, Fadhilah \& Anuar, 2019). The theory identifies student involvement as absorption in academic work, participation in extracurricular activities and interaction with faculty and other institutional personnel. The theory provides a platform to understand what and how environmental influences affect students' development and the kind of involvement that matters to achieve a specific outcome Hutchison, Niles, \& Trusty, 2016). It also portrays the degree of student involvement such as quality and quantity lead to certain development aspects and how the program, curriculum, policy or practices be designed to encourage student involvement (Binti, et.al., 2019). This theory best fits the study because, during the orientation program, students are informed about the nature of the university, they are introduced to their respective faculties and lecturers, they are shown around the university campus to make it easy for them to assess places on campus. life (Wischusen, Wischusen \& Pomarico (2011) defines orientation as comprising the capabilities and assets required for a means of living. Wischusen, et.al., (2011) indicate that orientation should be in a relaxed environment to enable participants being able to cope with the stresses to enhance their knowledge and capabilities both now and in the future. In line with Wischusen, et.al., conception, the University of Cape Coast developed an orientation program to sensitized fresh students to be abreast with academic and social life on campus.

Students are also oriented on their academic life, in which they are thought how to study and succeed in their academic activities. Various studies have pointed out that fresh students' orientation program is to allow them to have opportunities to learn about the college environment. Zweig, Hanita, Stafford \& Khanani (2021) indicate that the purpose of first-year orientation is to help the first-year student transition to a university setting. as cited in Evensen (2017) defined of orientation is to acquaint students with the administrative regulations and expected behaviors of the institution and to introduce them to student organizations and activities. Zweig, Hanita, Stafford \& Khanani (2021) state that each goal within orientation focuses on helping to develop students within the transition period before the academic year beginning. Such efforts allow first-year students to become better adjusted to their new social and academic life.

\section{Students view on the importance of orientation program}

The goal during orientation programs is to give students a realistic look at the pace of university life (Wischusen, Wischusen \& Pomarico, 2011). According to
Hutchison, Niles, \& Trusty (2016) the overall impact from a study conducted on first-year students is a transition, that is both academic and social transition. Hutchison, Niles, \& Trusty (2016) added that an orientation program helps new students to understand the things in the university and have a better expectation for college. Introducing new students into university life will give a better view of how the university is regulated, the acceptable and nonacceptable behaviors of the institution and also help the students find their way around the campus. It helps the students to know the dos and don'ts in the institution.

Students face challenges in adapting to the university system. As students become more involved in campus opportunities as a result of orientation, they get new friends and get to know the faculty and staff members. These students begin to feel a true connection to the campus community and also have a realistic view of the university. They see and integrate the good experiences with the challenges. The original home culture becomes somewhat foreign where there is less dependence on parents and former peers. A true sense of acceptance, integration and connectedness occurs when students have successfully adapted to their new learning environment through orientation (Owusu, Tawiah, SenaKpeglo \& Onyame, 2014). Integration into a new environment is very necessary because as a new student, familiarizing yourself with the campus, knowing your lecturers, lecture halls and other places will allow for easy access to important places thereby make staying in the university an easy one. Evensen (2017) asserted that orientation is the university's best opportunity to introduce a strong learning environment, build the foundations for academic success, welcome students and families to the campus community, promote student interactions with faculty and staff and convey the values and traditions of their new institution. Building retention is one of the influential purposes and hope of a first-year orientation program.

\section{Effect of Orientation on Academic and Social Life}

Social, academic and personal integration as cited by many studies is a key transitional element for freshmen during orientation (Alnawas, 2015). Zweig, Hanita, Stafford \& Khanani, (2021) claim academic advising, academic preparedness and tackling unrealistic expectations and career confusion are contributing factors to academic integration Zweig, Hanita, Stafford \& Khanani, (2021) states that academic integration of fresh students is important since it is the first step to graduating. A weak relationship between students and faculty is the most difficult part of the academic integration of students which is caused by a lack of understanding of job responsibilities. To achieve unity during orientation, the information gap should be bridged and in turn facilitate the academic integration of new students (Alnawas, 2015). Integrating new students socially has to do with obtaining autonomy and independence, introduction to intimacy and searching and development of identity. Strategies used to socially integrate new students into the campus community include socializing, teaching students in a 
lively way through peer and role play and small group sessions. Students can successfully integrate socially if they have expectations (Harmsen, Helms-Lorenz, Maulana, \& Veen, 2018). Alnawas (2015) mention that orientation provides new students with the experiences required for learning which helps students to adapt and understand change.

\section{STUDY METHODS}

The study was done at the University of Cape Coast, located in the Cape Coast University of Cape Coast is located in the Metropolis, off the Accra-Takoradi highway in the Central Region of Ghana. It is surrounded by settlements including Abura, Pedu, Duakor, Apewosika, Akotokyir, Kokoado, Kwesipra, Kwaprow and Amamoma. It is surrounded by settlements including Abura, Pedu, Duakor, Apewosika, Akotokyir, Kokoado, Kwesipra, Kwaprow and Amamoma.

It was established in October 1962 as a University College and placed in a special relationship with the University of Ghana, Legon. It was established in October 1962 as a University College and The University has five colleges namely; College of Agricultural and Natural Sciences, College of Humanities and Legal Studies, College of Education Studies, College of Health and Allied Sciences and College of Distance Education. The University of Cape Coast in 2020 has a total student population of 60,792 . Among these are 19,094 regular undergraduates, 1,785 sandwich undergraduate students, 837 regular postgraduate students, 2,809 sandwich postgraduate students, 33,016 distance undergraduate students and 3,251 postgraduate distance students (University of Cape Coast, 2019).

The study employed a cross-sectional design. The study population was first-year undergraduate students of the University of Cape Coast and the target population was the students who participated in the orientation service organized by the University in 2019. Data were obtained from a student who went through the orientation program in the 2019 academic year through purposive sampling. Data were also collected from an official who was involved in the orientation program as key informants in the University. The study was qualitative and an interview guide was developed and used for data gathering. The interview guide allowed the participants to freely express their opinions and also allowed the interviewer to ask follow-up questions based on the responses provided. Data was collected using a recorder from 2nd to 19th December 2019. Data were analyzed manually under broad themes and presented in the descriptive narrative mode using the thematic approach. Where appropriate and needful, a direct quotation of relevance from the respondents was used for illustration of the evidence. Training of field assistants, data collection and Two research assis[1]tants, each with a master's degree in qualitative research, were recruited and trained to assist with data collection. The training took 2 days - 3days for actual training and 1 day for pretesting of the data collection instruments. The feedback from the pretest was used to finalize the instrument.

\section{RESULTS AND DISCUSSIONS}

Results were grouped and presented under themes. The first segment touched on socio-demographic characteristics, general overview of the orientation. The second segment was on lessons learned and adapting to the new environment, educational activity that helped achieve educational goals, transitioning from an SHS leaver, expectations of the orientation and recommendations. Table 1 shows the socio-demographic characteristics of the students admitted in the 2019/20 academic year who took part in the study.

\section{Socio-demographic data}

The socio-demographic characteristics covered sex, ages, ethnicity, religion and program of study. The table indicates that about 27 of the students (54\%) were males and $23(46 \%)$ were females. Sixteen participants were between the ages of 18 and 20 years, 14 of them were between the ages of 21-22 years, 14 were between 23- 24 years and 6 of them were 25 years. With regards to ethnicity, 25 students were Akans, 8 were Ewes, 6 were Gonjas and Dangbane, Nzema and $\mathrm{Ga}$ each had 3 participants. Both Hausa and Frafra had a student participating. Forty out of the 50 student participants (80\%) were Christians, 9 (18\%) were Muslims and 1 Hindu. The students' programs of studies varied as presented in Table 1 .

Table 1: Socio-demographic characteristics of respondents

\begin{tabular}{|cc|c|c|c|c|c|}
\hline $\begin{array}{c}\text { Participan } \\
\text { t }\end{array}$ & Sex & $\begin{array}{c}\text { Ag } \\
\text { e }\end{array}$ & $\begin{array}{c}\text { Ethnic } \\
\text { ity }\end{array}$ & Religion & Program \\
\hline Student & 1 & Male & 25 & Akan & Christian & BSc Economics \\
\hline Student & 2 & Male & 21 & Ga & Christian & $\begin{array}{c}\text { BA Population and } \\
\text { Health }\end{array}$ \\
\hline Student & 3 & Male & 19 & Hausa & Muslim & Bed Social Science \\
\hline Student & 4 & Male & 21 & Akan & Christian & $\begin{array}{c}\text { BSc Biomedical } \\
\text { Science }\end{array}$ \\
\hline Student & 5 & Female & 20 & Ewe & Christian & BSc Nursing \\
\hline Student & 6 & Female & 20 & Ewe & Christian & BA Arts \\
\hline Student & 7 & Male & 19 & Akan & Christian & $\begin{array}{c}\text { BSc Laboratory } \\
\text { Technology }\end{array}$ \\
\hline Student & 8 & Female & 23 & Akan & Christian & BEd Arts \\
\hline Student & 9 & Male & 18 & Akan & Christian & Bachelor of Law \\
\hline Student & 10 & Female & 23 & Ewe & Christian & BA Social Science \\
\hline Student & 11 & Female & 19 & Ewe & Christian & $\begin{array}{c}\text { BEd Basic } \\
\text { Education }\end{array}$ \\
\hline Student & 12 & Male & 21 & Frafra & Christian & BSc Economics \\
\hline Student & 13 & Female & 18 & Akan & Christian & Bachelor of Law \\
\hline Student & 14 & Male & 18 & Ewe & Christian & BSc Sports \\
\hline Student & 15 & Male & 22 & Akan & Christian & $\begin{array}{c}\text { BA Population and } \\
\text { Health }\end{array}$ \\
\hline Student & 16 & Female & 22 & Akan & Christian & $\begin{array}{c}\text { BA Population and } \\
\text { Health }\end{array}$ \\
\hline Student & 17 & Female & 22 & Akan & Christian & $\begin{array}{c}\text { BA Population and } \\
\text { Health }\end{array}$ \\
\hline Student & 18 & Male & 19 & Ewe & Christian & BA Social Science \\
\hline Student & 19 & Male & 22 & Gonja & Christian & $\begin{array}{c}\text { BSc Geography and } \\
\text { Regional Planning }\end{array}$ \\
\hline
\end{tabular}




\begin{tabular}{|c|c|c|c|c|c|c|}
\hline Student 2 & & Male & 19 & Nzema & Christian & $\begin{array}{c}\text { B Com } \\
\text { Management }\end{array}$ \\
\hline Student 2 & 21 & Male & 20 & Akan & Christian & $\begin{array}{l}\text { BSc Procurement } \\
\text { and Supply Chain } \\
\text { Management }\end{array}$ \\
\hline Student 2 & 22 & Male & 20 & Akan & Christian & $\begin{array}{c}\text { BA Population and } \\
\text { Health }\end{array}$ \\
\hline Student 2 & 23 & Female & 22 & Akan & Christian & BA Arts \\
\hline Student 2 & 24 & Female & 23 & Gonja & Christian & BEd Mathematics \\
\hline Student 2 & 25 & Female & 20 & Akan & Christian & $\begin{array}{l}\text { BSc Medical } \\
\text { Sonography }\end{array}$ \\
\hline Student 2 & 26 & Female & 21 & $\begin{array}{c}\text { Dagba } \\
\text { ne }\end{array}$ & Muslim & BEd Management \\
\hline Student 2 & 27 & Male & 25 & Akan & Muslim & $\begin{array}{l}\text { BA Population and } \\
\text { Health }\end{array}$ \\
\hline Student 2 & 28 & Female & 23 & Akan & Muslim & $\begin{array}{c}\text { BSc Physician } \\
\text { Assistant Studies }\end{array}$ \\
\hline Student 2 & 29 & Female & 22 & Akan & Christian & $\begin{array}{c}\text { BA Population and } \\
\text { Health }\end{array}$ \\
\hline Student 3 & 30 & Male & 20 & Ewe & Christian & BA Social Science \\
\hline Student 3 & 31 & Male & 22 & Gonja & Christian & $\begin{array}{l}\text { BSc Geography and } \\
\text { Regional Planning }\end{array}$ \\
\hline Student 3 & 32 & Male & 22 & Nzema & Christian & BCom Management \\
\hline Student 3 & 33 & Male & 23 & Akan & Christian & $\begin{array}{l}\text { BSc Procurement } \\
\text { and Supply Chain } \\
\text { Management }\end{array}$ \\
\hline Student 3 & 34 & Male & 22 & Akan & Muslim & $\begin{array}{l}\text { BA Population and } \\
\text { Health }\end{array}$ \\
\hline Student 3 & 35 & Female & 24 & Akan & Christian & BA Arts \\
\hline Student 3 & 36 & Female & 25 & Gonja & Hindu & BEd Mathematics \\
\hline Student 3 & 37 & Female & 23 & Akan & Muslim & $\begin{array}{l}\text { BSc Medical } \\
\text { Sonography }\end{array}$ \\
\hline Student 3 & 38 & Female & 24 & $\begin{array}{c}\text { Dagba } \\
\text { ne }\end{array}$ & Muslim & BEd Management \\
\hline Student 3 & 39 & Male & 24 & Akan & Christian & $\begin{array}{l}\text { BA Population and } \\
\text { Health }\end{array}$ \\
\hline Student 4 & 40 & Female & 25 & Akan & Christian & $\begin{array}{c}\text { BA Population and } \\
\text { Health }\end{array}$ \\
\hline Student 4 & 41 & Male & 24 & Akan & Christian & $\begin{array}{c}\text { BSc Physician } \\
\text { Assistant Studies }\end{array}$ \\
\hline Student 4 & 42 & Male & 21 & Ewe & Christian & BA Social Science \\
\hline Student 4 & 43 & Male & 25 & Gonja & Muslim & $\begin{array}{l}\text { BSc Geography and } \\
\text { Regional Planning }\end{array}$ \\
\hline Student 4 & 44 & Male & 22 & Nzema & Christian & BCom Management \\
\hline Student 4 & 45 & Male & 23 & Akan & Christian & $\begin{array}{c}\text { BSc Procurement } \\
\text { and Supply Chain } \\
\text { Management }\end{array}$ \\
\hline Student 4 & 46 & Male & 22 & $\mathrm{Ga}$ & Christian & $\begin{array}{c}\text { BSc Physician } \\
\text { Assistant Studies }\end{array}$ \\
\hline Student 4 & 47 & Female & 24 & Akan & Christian & BA Arts \\
\hline Student 4 & 48 & Female & 25 & Gonja & Christian & BEd Mathematics \\
\hline Student 4 & 49 & Female & 23 & $\mathrm{Ga}$ & Christian & $\begin{array}{l}\text { BSc Medical } \\
\text { Sonography }\end{array}$ \\
\hline Student 5 & 50 & Female & 24 & $\begin{array}{l}\text { Dagba } \\
\text { ne }\end{array}$ & Muslim & BEd Management \\
\hline
\end{tabular}

Table 2: Time table for the 2019/20 orientation program for fresh students MONDAY, 26 ${ }^{\mathrm{TH}}$ AUGUST, 2019

\begin{tabular}{|c|c|c|}
\hline \multicolumn{3}{|c|}{ MORNING SESSION } \\
\hline ITEM & TIME & $\begin{array}{l}\text { RESOURCE } \\
\text { PERSONS }\end{array}$ \\
\hline Students Seated & 8:00am & \\
\hline Opening Prayer & 8:00am & University Chaplain \\
\hline Welcome Address & $8: 15 \mathrm{am}-8: 30 \mathrm{am}$ & Registrar \\
\hline $\begin{array}{l}\text { Address by Dean of } \\
\text { Students }\end{array}$ & 8:30am - 8:45am & Dean of. Students \\
\hline $\begin{array}{c}\text { Address by Director } \\
\text { DAPQA }\end{array}$ & 8:45am - 9:00am & Director, DAPQA \\
\hline $\begin{array}{c}\text { Overview of } \\
\text { Communicative Skills }\end{array}$ & 9:00am - 9:15am & $\begin{array}{l}\text { Dr. Eric Opoku- } \\
\text { Mensah }\end{array}$ \\
\hline Energy Conservation & 9:15am-9:30am & $\begin{array}{l}\text { Head, Electricity } \\
\text { Section }\end{array}$ \\
\hline $\begin{array}{c}\text { Religious Service in } \\
\text { UCC }\end{array}$ & 9:30am-9:45am & $\begin{array}{c}\text { Head, Chaplaincy } \\
\text { Board }\end{array}$ \\
\hline Fire Safety & 9:45am - 10:00am & Head, Fire Service \\
\hline Introductions & 10:00am - 10:10am & \\
\hline Question Time & 10:10am - 10:20am & \\
\hline Closing Remarks & $10: 20 \mathrm{am}-10: 25 \mathrm{am}$ & \\
\hline Closing Prayer & $10: 25 \mathrm{am}-10: 30 \mathrm{am}$ & \\
\hline \multicolumn{3}{|c|}{ AFTERNOON SESSION } \\
\hline ITEM & TIME & $\begin{array}{l}\text { RESOURCE } \\
\text { PERSONS }\end{array}$ \\
\hline $\begin{array}{l}\text { Overview of Faculty } \\
\text { of Arts \& Faculty of } \\
\text { Law }\end{array}$ & 11:00am - 12:00pm & $\begin{array}{l}\text { Deans and Heads of } \\
\text { Departments }\end{array}$ \\
\hline $\begin{array}{c}\text { Faculty/Department } \\
\text { Requirement for } \\
\text { Degrees }\end{array}$ & $12: 00 \mathrm{pm}-1: 00 \mathrm{pm}$ & $\begin{array}{l}\text { Deans and Heads of } \\
\text { Departments }\end{array}$ \\
\hline
\end{tabular}

TUESDAY, $27^{\mathrm{TH}}$ AUGUST, 2019

\begin{tabular}{|c|c|c|}
\hline ITEM & TIME & $\begin{array}{l}\text { RESOURCE } \\
\text { PERSONS }\end{array}$ \\
\hline $\begin{array}{c}\text { Campus Security } \\
\text { Services }\end{array}$ & 9:00am - 9:30am & Head of Security \\
\hline $\begin{array}{c}\text { Sporting Activities in } \\
\text { UCC }\end{array}$ & 9:30am - 10:00am & $\begin{array}{l}\text { Head, Sports } \\
\text { section }\end{array}$ \\
\hline $\begin{array}{c}\text { Regulations for Junior } \\
\text { Members }\end{array}$ & 10:00am - 10:30am & Prof. Koawu Edjah \\
\hline $\begin{array}{l}\text { Academic Programs, } \\
\text { Polices \& Regulations }\end{array}$ & 10:30am - 11:00am & $\begin{array}{l}\text { Mr. Emmanuel } \\
\text { Aidoo }\end{array}$ \\
\hline Anger Management & 11:00am - 11:30am & $\begin{array}{l}\text { Mrs. Anita Baaba } \\
\text { Turkson }\end{array}$ \\
\hline Break Time & 11:30am - 1:00pm & \\
\hline $\begin{array}{l}\text { Students'Counselling } \\
\text { Service in UCC }\end{array}$ & 1:00pm - 1:30pm & $\begin{array}{l}\text { Ms. Evelyn Esi } \\
\text { Brenya }\end{array}$ \\
\hline Disability Services & $1: 30 \mathrm{pm}-2: 00 \mathrm{pm}$ & $\begin{array}{l}\text { Mrs. Pearl Martha } \\
\text { Okine }\end{array}$ \\
\hline Registration Issues & $2: 00 \mathrm{pm}-2: 30 \mathrm{pm}$ & $\begin{array}{l}\text { Mr. Divine Selorm } \\
\text { Wemegah }\end{array}$ \\
\hline $\begin{array}{l}\text { Library Services for } \\
\text { Students }\end{array}$ & $2: 30 \mathrm{pm}-3: 00 \mathrm{pm}$ & $\begin{array}{l}\text { Mrs. Paulina } \\
\text { Afful-Arthur }\end{array}$ \\
\hline Health Services in UCC & $3: 00 \mathrm{pm}-3: 30 \mathrm{pm}$ & $\begin{array}{c}\text { Dr. (Mrs.) Oxama } \\
\text { Gorleku }\end{array}$ \\
\hline
\end{tabular}

The University has its time table for the orientation program every year. This is presented in table 2 . 
W EDNESDAY, $28^{\mathrm{TH}}$ AUGUST, 2019

\begin{tabular}{|c|c|c|}
\hline ITEM & TIME & $\begin{array}{l}\text { RESOURCE } \\
\text { PERSONS } \\
\end{array}$ \\
\hline Students Seated & 8:00am & \\
\hline $\begin{array}{c}\text { Structure of } \\
\text { University/Channels of } \\
\text { Communication } \\
\end{array}$ & 8:00am - 8:20am & Director, DHR \\
\hline Security Matters & 8:20am - 8:40am & $\begin{array}{l}\text { Head of } \\
\text { Security }\end{array}$ \\
\hline $\begin{array}{l}\text { Overview of Centre for } \\
\text { International Education }\end{array}$ & 8:40am - 9:00am & Director, CIE \\
\hline ICT Services on Campus & 9:00am - 9:20am & Director, ICT \\
\hline $\begin{array}{l}\text { Presentation on Confucius } \\
\text { Institute }\end{array}$ & 9:20am - 9:40am & $\begin{array}{l}\text { Prof. Ishmael } \\
\text { Mensah }\end{array}$ \\
\hline $\begin{array}{c}\text { Presentation on Study } \\
\text { Habit }\end{array}$ & 9:40am - 10:00am & $\begin{array}{l}\text { Dr. Eugene } \\
\text { Johnson }\end{array}$ \\
\hline Students Loan Scheme & 10:00am - 10:10am & $\begin{array}{l}\text { Mr. Samuel } \\
\text { Apaah }\end{array}$ \\
\hline $\begin{array}{c}\text { Introduction of SRC, Local } \\
\text { NUGS and GRASAG } \\
\text { Executives } \\
\end{array}$ & 10:10am - 10:20am & \\
\hline Question Time & 10:20am - 10:40am & \\
\hline $\begin{array}{c}\text { Chairman's Closing } \\
\text { Remark }\end{array}$ & 10:40am - 10:45am & \\
\hline $\begin{array}{c}\text { UCC Anthem by } \\
\text { Department of Music }\end{array}$ & 10:45am - 11:00am & $\begin{array}{c}\text { Department of } \\
\text { Music }\end{array}$ \\
\hline Campus Tour & 11:00am - 3:00pm & \\
\hline $\begin{array}{c}\text { Meeting with Hall } \\
\text { Masters/Warden and Hall } \\
\text { Tutors }\end{array}$ & $5: 00 \mathrm{pm}-6: 30 \mathrm{pm}$ & \\
\hline
\end{tabular}

THURSDAY, $29^{\mathrm{TH}}$ AUGUST, 2019

\begin{tabular}{|c|c|c|}
\hline ITEM & TIME & $\begin{array}{c}\text { RESOURCE } \\
\text { PERSONS }\end{array}$ \\
\hline Students Seated & $9: 00 \mathrm{am}$ & \\
\hline Campus Tit bits & $9: 00 \mathrm{am}-4: 00 \mathrm{Pm}$ & Director, CEGRAD \\
\hline
\end{tabular}

FRIDAY, 30 ${ }^{\mathrm{TH}}$ AUGUST, 2019

\begin{tabular}{|c|c|c|}
\hline ITEM & TIME & $\begin{array}{c}\text { RESOURCE } \\
\text { PERSONS }\end{array}$ \\
\hline Students Seated & $9: 00 \mathrm{am}$ & \\
\hline Campus Tit bits & $9: 00 \mathrm{am}-4: 00 \mathrm{pm}$ & Director, CEGRAD \\
\hline
\end{tabular}

The students viewed orientation as helping them know their way through the university as reported by two of them:

Well, looking at us being fresh students coming to a very big place like this university, I don't think we would have been able to get to know places like the lecture halls and sectors where we could easily get help. The orientation was helpful because it made us know places that were unknown to us (20year-old, female B.A. Arts student \& 24-year old, BEd Management).

Three other students also remarked that:

As fresh students when we came, we didn't know our whereabouts but because of the orientation, the ushers took us around. They showed us some parts of the University and we got acquainted with the places (22-year-old male Population and Health).
In a nutshell, the orientation was beneficial because it helped us to easily locate a place. For example, walking from the North Campus (New Site) to the South Campus (Old Site) without a guided tour would be difficult for a fresh student (20-year-old female B.Ed. Mathematics student, 23 - year old BSc Medical Sonography, 22-year- old BSc Physician Assistant Studies).

\section{Duration for the orientation}

How many days were for the orientation program (Provide time table for the program?)

The program was for 5 days. The orientation program was good, but the time of sitting was too long. Sitting down from 8:00 am to 2:00pm and then from 3:00 pm to 5:00 pm was too stressful. (21-year-old, B. A Population and Health, 23 -yearold, BEd Mathematics, 25-year-old BSc Geography and Regional Planning).

Areas touched on during orientation

Another segment of an orientation program in the area (s) of discussion. From the responses provided, the areas touched on were academic life, social life, security, sexual harassment, and medicals.

Academic life

Academically, we were divided into groups and informed about the courses that were offered. When we got to the faculty and departmental level, the Deans, HOD's and lecturers assisted us in knowing the courses we were to pursue, how to go about it, how to locate our lecture halls amongst other things (20-year-old, B.A Arts student).

On the second day, we were grouped into our various departments and were told how to register for our courses. We were also briefed on the kinds of people we would meet (22-year-old, BSc Geography and Regional Planning student, 22- year-old, 23-year-old BCom Management, BSc Procurement and Supply Chain Management).

\section{Social life}

My problem was the location. Fortunately, some billboards aided me. Things are well structured and the organization of social activities was also goo19-year-old d (20-year-old, B.A Arts student).

We were told to be very extra careful. We were given students' guides and books containing rules and regulations, the norms of the school and how to conduct one's ourselves in the school. I think that's to help students know the acceptable ways of living in the university (25-year-old, BSc Economics student, 23-year-old BSc Medical Sonography, 24-year-old BEd Management).

They emphasized the academic purpose: why we came to school. We were entreated to take our studies seriously. We could participate in social events but not at the expense of our studies (19-year-old, Bed Social Science student). 


\section{Security}

"The resource persons talked about security and how the students can comfortably stay in the university whilst studying peacefully" (19-year-old, BSc Laboratory Technology).

"With the security aspect, we were advised not to leave campus after 9:30 pm. and suggested we all remain in our halls but not at our respective faculties on campus. We were also warned to keep items such as phones and laptops safely as theft cases were prevalent" (22-year-old, B.A Population and Health student, 25-year-old, BEd Mathematics).

\section{Sexual harassment}

"With the issue of sexual harassment, we were enlightened on the possibilities of certain incidents which could lead to our demise from the school. An example was when you sexually confront a lady without her permission and she reports you to the authorities, you are likely to be sacked" (20-year-old, BEd Mathematics student).

"They taught us how to behave well on campus and also not to seduce the other sex. Decent dressing was required from all of us. Disregarding this important instruction was to our detriment." (21-year-old, Bed Management student, 25-yearold, BA Population and Health, 23-year-old BSc Physician Assistant Studies).

\section{Medical examination}

"We were told to go for medical examination at the university hospital to complete our registration process. This was required to ensure we were in the best possible state of health to successfully pursue our programs" (20-year-old, BEd Mathematics student, 22-year-old BA Population and Health)

"The resource person told us if we encountered any health problems, we could go to the hospital on campus." (22-yearold Bachelor of Arts student, 20-year-old BA Social Science).

Important things learned during orientation

It was prudent to find out the important thing(s) learned during the orientation. Therefore, their responses were grouped into time management, influence on academic and social lives.

Time management

"One thing I learned during the orientation was that, we should learn how to manage our time and the resources available to us in the university" (23-year-old Bed Arts student, 22-year-old BSc Geography and Regional Planning).

"During the orientation, I learned how to manage my time, do my timetable and plan my activities to ease tension on my stay on campus" (19-year-old BEd Basic Education).

"When asked why time management was important, this is what the respondent had to say.
"If you don't manage your time well, you will waste your time here doing unnecessary things"(19-year-old BEd Basic Education, 20-year-old BA Social Science).

Influence on academics

Responses provided showed that the orientation program influenced the students' academic and social lives.

I learned that in the university, you must research and learn on your own and not solely depend on the lecturers (22-yearold, Population and Health student).

\section{Influence on social life}

"We have moved to a new environment and we are meeting new people. This is going to affect us but we have the power to decide whether it will be for the best or to our disadvantage" (21-year-old, BSc Economics student).

"I think the perception I used to have about people changed when I met people of different backgrounds and origins in the university. This has helped me a lot in my interactions and also improved my social skills" (22-year-old, BSc Geography and Regional Planning).

Influence on choice and selection of courses

"My courses were certified. There was no need for auditing. A certain number of courses were already in the portal so there was nothing I could do about it" (19-year-old, BSc Laboratory Technology).

"The courses given me were standard. I didn't select or drop any courses. They were all default courses with two elective courses" (18-year-old, Bachelor of Law student).

"As for the courses, they were given to us automatically. We didn't select anything." (23-year-old, B. Com Procurement, and Supply Chain Management student)

From the responses provided, it was deduced that the courses were prescribed for them and the students had no choice in the selection of their first semester's courses.

Academic programs

"During the orientation, we were told if we had any problem with a particular course or any particular lecturer, we could make a report or a complaint so that we would be advised on how to handle that particular course and how to behave during the lectures or a particular lecture that we had a problem with (19-year-old BSc Laboratory Technology).

"During the orientation, the major topic was academic programs. The resource persons spoke lengthily about it. We were advised to learn hard and not waste time doing unnecessary things. We were advised to make our books our friends" (19-year-old BEd Basic Education).

Adapting to a new environment

A very easy way for the students to adapt to their new environment was through taking a tour within the university community. The responses provided includes; 
"During the last part of the orientation program, we were sent out on a walk by certain university personnel. They showed us all the major landmarks and buildings in the school. These include lecture theaters, departmental buildings, the congregational grounds and the main University Library. It helped us" (25-year-old, BSc Economics student).

"As part of our orientation, we embarked on a campus tour to acclimatize ourselves with our new environment" (19-yearold, Bed Social Science student).

"Some days after we arrived, they took us around the university and it has helped a lot. This

is because at first, we couldn't find our way around campus" (20-year-old, Nursing student)

An educational activity that helped achieve educational goals

Attaining an educational goal is important to every student. Therefore, it was important to know whether the educational activity organized during the orientation program helped the students achieve their educational goals. Below are some of the responses provided by the students.

Achieving educational goals

"The orientation helped because everything was systematic. It helped me to schedule my studies very well" (25-year-old, BSc Economics student).

"After the orientation, I am now able to differentiate between the time to learn and the time to play. I also learned that to be able to recall sufficient information for my tests and exams, I need enough rest before my respective papers" (19-year-old, BEd Social Science student).

"During the orientation, we were told to form study groups. I now find myself in various study groups and I have benefitted a lot" (21-year-old Biomedical Science student).

The transition from Senior High School (SHS)

In a university community where no one will tell you when to attend classes like in the SHS and also where there are no parents around to tell you what to do, a critical area looked at was how the students were able to transition from SHS school leavers to University students. The responses provided elaborated on how some of these students transitioned.

"It was explained to us that bells are not ringing for us to attend lectures in the university. Also, all the necessary information could be found on various notice boards so hearsays are not encouraged" (19-year-old Bed Social Science student).

"We were told that the university is not like the SHS. Sirens were not going to be sounded for important conveyances or when there is the need for information to be passed. We then prepared when we heard these things because we realized this was going to be something new" (20-year-old nursing student).
"We were encouraged to be on our own because no prefects were going to force us to behave acceptably in the university. We were also advised to be disciplined enough to study on our own because no one was going to force us to study" (20-yearold Bed Mathematics student). "We were also told to take cues from the stances of the statues on campus. Most of the statues are holding books and this was interpreted as the only form of communication suggesting we had to study on our own" (20-year-old Bed Mathematics student).

\section{A sense of maturity}

"During the orientation, we were treated like adults. They spoke to us as mature individuals and not as children. They made us feel we were old enough to know how to behave acceptably in society and therefore we were to take responsibility for our actions" (20-year-old Sonography student).

"They made us understand that we are now grownups and so we should let go of our foolish childish ways. This has greatly influenced my conduct in school." (20-year-old Population and Health student)

\section{Expectations of the orientation}

Expectations of the orientation program were grouped into 'met and unmet expectations. The responses outlined depict the expectations of the orientation. This came with mixed feelings.

\section{Met expectations}

"The orientation program met my expectations. I got important hints and tips on how to live properly on campus. Joining groups like AGOOD, I cultivated the idea of greatly improving my academics by building my CGPA right from level 100" (17-year-old Bachelor of Law student).

\section{Unmet expectations}

"I was not satisfied. I expected more than what they did. I felt there was more than enough time to go into details with regards to our respective courses but they scratched just the surfaces" (21-year-old Population and Health student).

The orientation program should be spread within 2 weeks so we could get more of it (21-year-old Population and Health student, 20-year -old BA Social Science).

Timing for the orientation program

Positively,

"It was perfect. We are fresh in the university so organizing the orientation program at this particular time helped us (fresh students) to know what is expected of us, what to study in the university and how they should plan their time for academics and other things" (21-year-old, Biomedical Science).

"It was very good because if it hadn't been for the orientation organized within that week, a lot of us would have lost our ways on campus and we might have been harmed because we 
didn't know where exactly to go. Also, the most important aspect that helped us was the registration of the course." (20year-old Medical Sonography student).

The orientation should start earlier. I think our orientation started at 8:00 am. Although 8:00 am is quite good a time, I feel it should have started earlier around 7:00 am so that we could have easily moved on to other matters in our halls or at the departments (19-year-old Laboratory Technology student).

I think more time should be added to the orientation. The students will then acquire extra knowledge about what they are to pursue in the university amongst other important information (21-year-old Biomedical Science student).

Negatively,

"Organising the orientation in the first week wasn't right because others came the following week. I have a couple of friends who didn't come for the orientation because they had their admission letters late. Some came after the orientation and missed out on a great deal of firsthand information" (21-year-old Population and Health student).

I $w$ recommend that the university do something about the timing. Instead of organizing it in the first week, it can be pushed to the middle of the semester to enable every fresh student in the school to participate" (22-year-old Population and Health student).

"The length of the whole orientation program was a bit long especially the number of days it took to complete it. The duration per session was also long. They should reduce the number of people who come to talk to us. They are too many" (20-year-old Medical Sonography student).

\section{RESULTS AND DISCUSSIONS}

The orientation program organized for the fresh students was a fruitful one although there were some challenges. The views provided by the students showed that the orientation program organized by the management of the institution was very important because, as fresh students, they needed guidance in a new environment. All the students interviewed participated in the orientation program. With regards to the general overview of the program, the students assert that finding their way around the university community was talked about a lot since they were in a new environment and did not know their way around. During the orientation, the areas touched on included the academic and social lives of the students, security, sexual harassment and medical examination. From their responses, it was seen that these areas touched were very important.

The students considered time management as an important lesson during the orientation because they felt if they can manage their time, they would not end up wasting their time on unnecessary things. The students also appreciated the effect of the program on their academic and social lives. The program did not have any effect on the choice and selection of their course because their courses were automatically selected for them by the school. With regards to adapting to their new environment, their worries were eased with the help of the tour which was organized on the last day of the orientation program. According to some students, the didactic nature of the orientation helped them schedule their time to learn, play and rest as a way of achieving their educational goals. Also, some asserted that learning in study groups has also helped as it was advised under the orientation program. Transitioning from SHS to university was not an easy process according to them since there were no sirens to wake them up, no bells ringing to commerce classes, or time for learning and eating. Since they were told all these things during the orientation program, it prepared them for the semester and the rest of their stay on campus. Others also felt a sense of maturity since the management of the school addressed them as mature people and not as children.

During the orientation, some of the expectations of the students were met whilst others were not. Some of the met expectations include the fact that they were hinted at how to live on campus with regards to their academic and social lives. The unmet expectations include the fact that the management wasted too much time and left out important things like the details on the courses of study. It could be seen that the students gave out responses based on their personal experiences at the orientation program.

\section{CONCLUSION}

The study seeks to examine the views of students on orientation programs organized for fresh students at the University of Cape Coast. The idea of orientation programs for fresh students is to help them adapt to the university system with ease. Some organizations and institutions do recognize their responsibility towards the fresh students' orientation as part of their core values and therefore make significant preparations towards that. Colleges, faculties and departments in the University of Cape Coast do get involved to make the stay of these fresh students successful.

The study provided evidence that the orientation programs were successful in terms of affecting the academic and social lives of the students. Students were able to adapt to their new environment with the help of the tour. Secondly, the transition from SHS to university was made easier for the fresh students because the orientation made the students aware of the things being done in the secondary schools which were not done in the university. Thirdly, not everyone's expectations were met after the program. Some expected more to be discussed, especially matters relating to courses offered by the university whilst others taught it was a crushed program and therefore stressful.

In conclusion, the organization of the orientation program has implications on the learning outcomes and stress level of the students, thus supporting the arguments of the students' improvement theory. It is prudent for the university 
authorities to embark on an assessment of the orientation program in the University to address some of the lapses identified by the students.

\section{RECOMMENDATIONS}

Having identified some benefits and challenges regarding orientation programs for fresh students in the university and their potential impact on the students, we wish to make the following recommendations that could help improve upon the orientation program for fresh students at the University of Cape Coast.

1. The university should consider the timing for the orientation programs for fresh students to be in the 2nd week of reopening for most of the students to benefit. This is because some of the students receive their admission letters late the come to the campus in the second week instead of the stipulated date.

2. Some students indicated they get too tied due to the long period of the orientation program. This program can be spread within two weeks to ease the stress on students and also add more relevant topics to benefit the students.

3. After orientation programs, students should be given assessment forms to assess the general program and to identify where students have challenges. The challenges can be addressed in the next orientation program.

4. The University should plan for online orientation program for students. This will enable those who report late to participate in the program.

\section{REFERENCES}

[1] Alnawas (2015). Students orientation in higher education: development of the construct. Journal of Higher Education: 69 (4), 625-652.
[2] Chavez, K. (2015). First-year Seminars: Gateway to Success at Carolina. Retrieved from http://fys.unc.edu/first-year-seminarsgateway-to-success-at-carolina

[3] Evensen, K. (2017). Benefits and Level of Satisfaction a FirstYear Orientation Program Delivers or Freshmen in College. New York: River publishers.

[4] Harmsen, R., Helms-Lorenz, M. Maulana, R \& Veen, K. V. (2018). The relationship between beginning teachers' stress causes, stress responses, teaching behavior and attrition: teachers and teaching 24:6, 626-643.

[5] Hutchison, B., Niles, S. G., \& Trusty, J. (2016). Career developme nt interventions in the

schools. In B.T. Erford (3rd Ed.), Professional school counselling: A hand-book of theories, programs and practices. (3rd Ed.). Austin, TX: Pro-Ed.

[6] Mullendore, R. H., \& Banahan, L. A. (2005). Designing orientation programs. challenging and supporting the first-year student: A handbook for improving the first year of college, 391409.

[7] irul). Orientation impact on performance of undergraduate students in University of Cape Coast (Ghana). International Journal of Educational Administration and Policy Studies, 6 (7), $131-140$.

[8] Wischusen, S. M., Wischusen, E. W., \& Pomarico, S. M. (2011). Impact of a short pre-freshman program on retention. Journal of College Student Retention: Research, Theory \& Practice, 12(4), 429-441.

[9] Fox, C., Morris, S. (2021). Evaluating outcome-based payment for evidence based policy: Journal of economic policy reform, 24:1, 61-77.

[10] Ha P. L_\& Fry G. W. (2021). International educational motilities and new developments in Asia's higher education: Putting transformations at the center of inquiries, Research in comparative international education:16 (3).

[11] Sharma, Kim, J. \& Bryan, J. (2017). The Effects of purpose orientations on recent high school graduates' college application decisions: Journal of College Access: 3(2), 98-114.

[12] Zweig, J., Hanita, M. Stafford E. \& Khanani, N. (2021) Impact of an orientation on online students' course outcomes, Journal of Research on Technology in Education DOI: $\underline{10.1080 / 15391523.2021 .1911007}$ 